\title{
A Case of Malignant Pheochromocytoma with Holt-Oram Syndrome
}

\author{
AI YOSHIHARA, AKIYO TANABE, HIROSHI SAITO, NAOMI HIZUKA, AKIRA ISHIZAWA*, REIKO \\ HORIKAWA* AND KAZUE TAKANO
}

Department of Medicine, Institute of Clinical Endocrinology, Tokyo Women's Medical University, Tokyo 162-8666, Japan

*National Center of Child Health and Development, Tokyo 177-8535, Japan

\begin{abstract}
A 23-year-old female patient with malignant pheochromocytoma was admitted to the Tokyo Women's Medical University. The patient had been clinically diagnosed with Holt-Oram syndrome at birth. Since she had complex congenital heart disease, chronic heart failure, and severe hypoxia, the risk surrounding surgery to remove the primary tumor was predicted to be very high, and subsequently, chemotherapy was performed. The patient was not able to continue chemotherapy due to adverse effects. However, for one year, both her hypertension and catecholaminedependent symptoms were well controlled by an alpha-adrenergic and beta-adrenergic receptor blockade, although the patient did experience high plasma norepinephrine levels. To our knowledge, this is the first report of a patient with the combination of malignant pheochromocytoma and Holt-Oram syndrome. A correlation between chronic hypoxia and pheochromocytoma has been reported. This instructive case reminds us to consider the possibility of pheochromocytoma with congenital heart disease when these types of unexpected or unusual symptoms are encountered.
\end{abstract}

Key words: Malignant pheochromocytoma, Holt-Oram syndrome

(Endocrine Journal 55: 153-159, 2008)

HOLT-ORAM syndrome, also called the heart-hand syndrome, is an inherited disorder that causes anomalies of the upper limbs and heart [1-4]. The prevalence of this disorder has been estimated to be 0.95 per 100,000 total births [5]. The incidence of malignant pheochromocytoma is also very rare, accounting for $2.5 \%$ to $13 \%$ of pheochromocytomas (prevalence 0.8 per 100,000) $[6,7]$. Although cases of pheochromocytoma associated with congenital heart disease have been described in the literature, no case of malignant pheochromocytoma accompanied by Holt-Oram syndrome has been reported. We present the first case of cyanotic complex congenital heart disease of HoltOram syndrome associated with malignant pheochro-

Received: August 3, 2007

Accepted: October 9, 2007

Correspondence to: Ai YOSHIHARA, M.D., Department of Medicine, Institute of Clinical Endocrinology, Tokyo Women's Medical University, 8-1 Kawada-cho, Shinjuku-ku, Tokyo 1628666, Japan mocytoma (extra-adrenal abdominal pheochromocytoma) with multiple liver and bone metastases. We use the term pheochromocytoma to indicate tumors located in the adrenal glands, and extra-adrenal abdominal and thoracic locations, according to a previous report [8].

\section{Case Report}

A 23-year-old female patient with malignant pheochromocytoma was admitted to the Tokyo Women's Medical University in 2005. At birth, the patient had been clinically diagnosed with Holt-Oram Syndrome due to severe cyanosis resulting from complex congenital heart disease (dextrocardia, a single ventricle, and pulmonary atresia) and bilateral agenesis of the radial bone and first finger. Genetic analysis was not performed. The patient experienced meningitis when she was one year old, resulting in complete deafness. She underwent heart surgery when she was two years old and again at ten. Her condition was carefully followed 


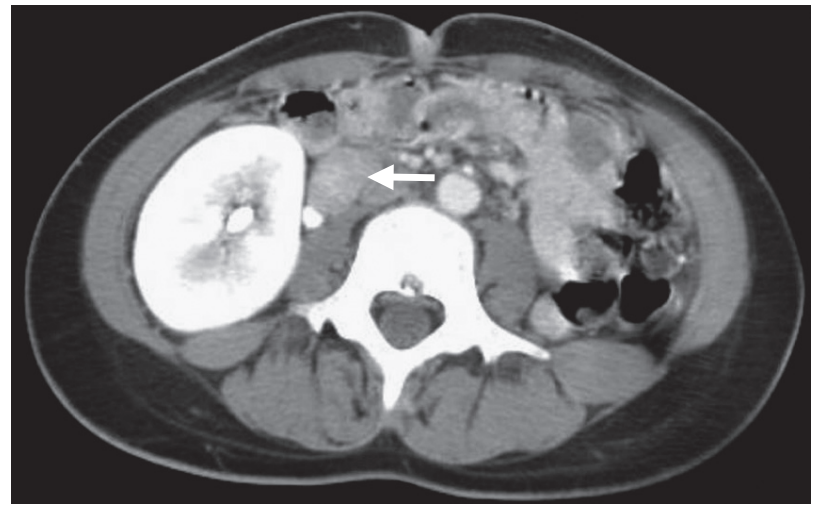

Fig. 1. Computed tomography of the abdomen demonstrated a soft tissue mass located behind the right kidney that was $23 \mathrm{~mm}$ in diameter.

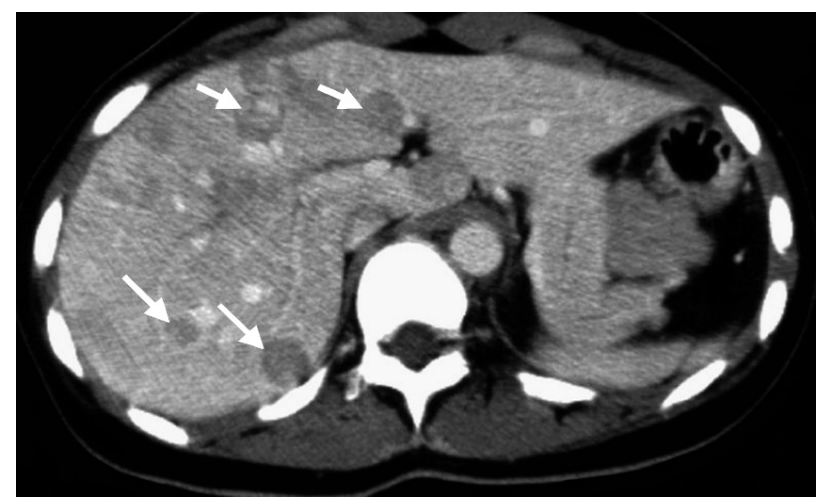

Fig. 2. Computed tomography of the abdomen demonstrated multiple nodular lesions in the liver.

up on a continuing outpatient basis by the pediatric cardiology department of the National Center of Child Health and Development.

The patient became aware of hyperhidrosis when she was 20 years old, and began to experience palpitations and effort-dependent dyspnea at 22 years old. At the age of 23, she was admitted to the National Center of Child Health and Development for acute heart failure. She had episodes of sudden increases in systolic blood pressure to $160 \mathrm{mmHg}$ accompanied by headaches and palpitations. Plasma norepinephrine levels $(7283 \mathrm{pg} /$ $\mathrm{ml}$ ) were significantly elevated, while plasma epinephrine levels remained normal $(38 \mathrm{pg} / \mathrm{ml})$. Computed tomography (CT) of the abdomen demonstrated a soft tissue mass located behind the right kidney that was $23 \mathrm{~mm}$ in diameter, as well as multiple nodular lesions in the liver (Fig. 1,2). The left kidney was congenitally atrophic and the right kidney showed compensatory

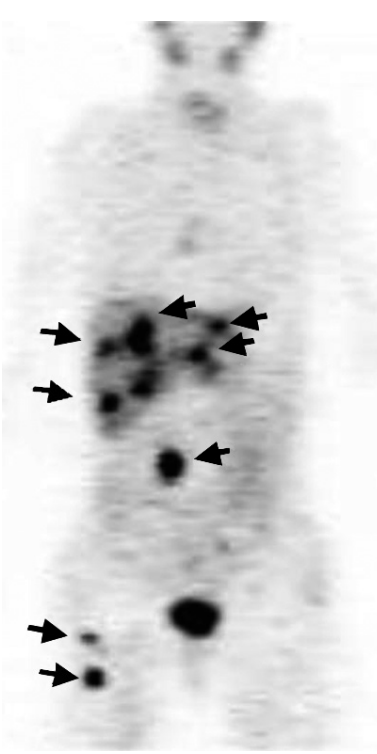

Fig. 3. Iodine-labeled metaiodobenzylguanidine scintigraphy revealed an intense accumulation in the right abdomen, multiple intense accumulations in the liver and right femur, and multiple moderate accumulations in the thoracic and lumbar spine.

hypertrophy. The bilateral adrenal glands appeared to be intact. Iodine-labeled metaiodobenzylguanidine ( $\left.{ }^{131} \mathrm{I}-\mathrm{MIBG}\right)$ scintigraphy demonstrated an intense accumulation in the right abdomen, multiple intense accumulations in the liver and right femur, and multiple moderate accumulations in the thoracic and lumbar spine (Fig. 3).

Findings were compatible with a diagnosis of malignant pheochromocytoma (extra-adrenal abdominal pheochromocytoma) with multiple liver and bone metastases, and the patient was referred to the Tokyo Women's Medical University for further evaluation and management. On admission, the patient stood $150 \mathrm{~cm}$ tall and was $40.5 \mathrm{~kg}$ in weight. Her blood pressure, measured from her thighs because of the atrophy of the upper extremities, was $112 / 74 \mathrm{mmHg}$ under medication with the alpha-adrenergic receptor blocker, prazosin $(1.5 \mathrm{mg} /$ day $)$. Her heart rate was 80 beats per minute (bpm) and regular. Her lips and extremities showed severe cyanosis. She had bilateral hearing disturbances, accompanied by bilateral Duane Syndrome, which consists of limitation of eye abduction associated with retraction of the eye globe and narrowing of the palpebral fissure on adduction. There was no familial history of hypertension or congenital anomalies.

A complete blood cell count revealed polycythemia 
Table 1. Laboratory data on admission

\begin{tabular}{ll}
\hline WBC & $10.26 \times 10^{3} / \mathrm{mm}^{3}$ \\
RBC & $6.11 \times 10^{6} / \mathrm{mm}^{3}$ \\
Hb & $19.8 \mathrm{~g} / \mathrm{dL}$ \\
Ht & $56.7 \%$ \\
Platelet & $20.5 \times 10^{4} / \mathrm{mm}^{3}$ \\
T-prot & $6.9 \mathrm{~g} / \mathrm{dL}$ \\
Alb & $3.9 \mathrm{~g} / \mathrm{dL}$ \\
T-bil & $1.0 \mathrm{mg} / \mathrm{dL}$ \\
AST & $35 \mathrm{IU} / \mathrm{L}$ \\
ALT & $25 \mathrm{IU} / \mathrm{L}$ \\
LD & $327 \mathrm{IU} / \mathrm{L}$ \\
ALP & $275 \mathrm{IU} / \mathrm{L}$ \\
$\gamma$ GTP & $76 \mathrm{IU} / \mathrm{L}$ \\
BUN & $13.8 \mathrm{mg} / \mathrm{dL}$ \\
Cr & $0.67 \mathrm{mg} / \mathrm{dL}$ \\
UA & $4.9 \mathrm{mg} / \mathrm{dL}$ \\
Na & $136 \mathrm{mEq} / \mathrm{L}$ \\
K & $4.4 \mathrm{mEq} / \mathrm{L}$ \\
Cl & $99 \mathrm{mEq} / \mathrm{L}$ \\
Ca & $9.9 \mathrm{mg} / \mathrm{dL}$ \\
P & $4.1 \mathrm{mg} / \mathrm{dL}$ \\
TG & $91 \mathrm{mg} / \mathrm{dL}$ \\
T-cho & $247 \mathrm{mg} / \mathrm{dl}$ \\
HDL-C & $91 \mathrm{mg} / \mathrm{dL}$ \\
CRP & $0.16 \mathrm{mg} / \mathrm{dL}$ \\
FBS & $101 \mathrm{mg} / \mathrm{dL}$ \\
IRI & $6.5 \mathrm{mU} / \mathrm{ml}$ \\
HbA1c & $6.7 \%$ \\
\hline
\end{tabular}

WBC, white blood cells; RBC, red blood cells; Hb, hemoglobin; $\mathrm{Ht}$, hematocrit; T-prot, total protein; Alb, albumin; T-bil, total bilirubin; AST, asparate aminotransferase; ALT, alanine aminotransferase; LD, lactate dehydrogenase; ALP, alkaline phosphatase; $\gamma$ GTP, $\gamma$-glutamyl transpeptidase; BUN, blood urea nitrogen; $\mathrm{Cr}$, creatinine; UA, uric acid; $\mathrm{Na}$, sodium; K, potassium; $\mathrm{Cl}$, chloride; $\mathrm{Ca}$, calcium; $\mathrm{P}$, phosphorous; TG, triglyceride; $\mathrm{T}$ cho, total cholesterol; HDL-C, HDL-cholesterol; CRP, C-reactive protein; FBS, fasting blood sugar; IRI, immunoreactive insulin; HbA1c, glyco hemoglobin A1c

(red blood cells $6.11 \times 10^{6} / \mathrm{mm}^{3}$, hemoglobin $19.8 \mathrm{~g} / \mathrm{dl}$, hematocrit 56.7\%) and leucocytosis (white blood cells $\left.10.26 \times 10^{3} / \mathrm{mm}^{3}\right)$ (Table 1). Other major laboratory findings, including electrolytes, renal function, and liver function, were within normal limits (Table 1). Endocrine investigation showed extremely elevated levels of plasma norepinephrine $(10985 \mathrm{pg} / \mathrm{ml})$ and urinary normetanephrine (12.79 mg/day) (Table 2$)$. Chest X-ray examination revealed dextrocardia (Fig. 4a). Two-dimensional echocardiography showed only a single ventricle, but contraction seemed almost normal. Her arterial blood gas data showed severe hypoxia ( $\mathrm{pCO}_{2} 40.2 \mathrm{mmHg}, \mathrm{pO}_{2} 48.8 \mathrm{mmHg}$, hemoglobin oxy-
Table 2. Endocrine data on admission

\begin{tabular}{llll}
\hline & & & Normal range \\
\hline \multirow{2}{*}{ Serum } & Adrenaline & $38 \mathrm{pg} / \mathrm{ml}$ & $<100$ \\
& Noradrenaline & $10985 \mathrm{pg} / \mathrm{ml}$ & $100-450$ \\
& Dopamine & $23 \mathrm{pg} / \mathrm{ml}$ & $<20$ \\
\multirow{4}{*}{ Urinary } & Metanephrine & $0.34 \mathrm{mg} /$ day & $0.05-0.23$ \\
& Normetanephrine & $12.79 \mathrm{mg} /$ day & $0.07-0.26$ \\
\hline
\end{tabular}

gen saturation $87.4 \%$ ) because of the complex cyanotic congenital heart disease. An X-ray of her arms showed bilateral agenesis of the radial bone and first finger (Fig. 4b, c). There were no osteolytic or osteosclerotic changes of the spinal bone or bilateral femur. The patient suffered from sweating, headaches, palpitations, general fatigue, and vertigo. After administration of the alpha-adrenergic receptor blocker, doxazosin ( $3 \mathrm{mg} /$ day), her episodes of sudden increase in systolic blood pressure improved, but her heart rate increased to $100-120 \mathrm{bpm}$ and the beta-adrenergic receptor blocker, carvedilol (1.25 mg/day), was administered. By increasing the doses of doxazosin $(6 \mathrm{mg} /$ day $)$ and carvedilol ( $2.5 \mathrm{mg} /$ day), her blood pressure and heart rate were controlled at normal levels and her symptoms improved.

Since the patient had complex congenital heart disease and chronic heart failure, the risk of using general anesthesia was thought to be very high, so an operation to remove the primary tumor of the pheochromocytoma, as well as radiofrequency ablation for the multiple hepatic metastases was not an option. Transcatheter arterial embolization was not indicated, since adriamycin has toxic consequences on cardiac function. The patient had to stay in the hospital room without any assistance during the 131I-MIBG therapy. Since she had several malformations of the extremities and required various assistance for her daily activity, 131I-MIBG therapy was not indicated. Subsequently, chemotherapy with a combination of cyclophosphamide $(750 \mathrm{mg} /$ $\mathrm{m}^{2}$ BSA), vincristine $\left(1.4 \mathrm{mg} / \mathrm{m}^{2} \mathrm{BSA}\right)$, and dacarbazine $\left(600 \mathrm{mg} / \mathrm{m}^{2} \mathrm{BSA}\right)$ on day 1 , and another dose of dacarbazine $\left(600 \mathrm{mg} / \mathrm{m}^{2}\right.$ BSA $)$ on day 2 , were performed $[6,9]$. Unfortunately, the patient suffered from severe adverse effects while on this regimen, including nausea, loss of appetite, headache, flushing of the face, sensory sensitivity and alopecia. In addition, she had transient liver dysfunction, the worst occurring on day 4 asparate aminotransferase (AST) $110 \mathrm{IU} / \mathrm{L}$, alanine aminotransferase (ALT) $110 \mathrm{IU} / \mathrm{L}\}$, and transient 


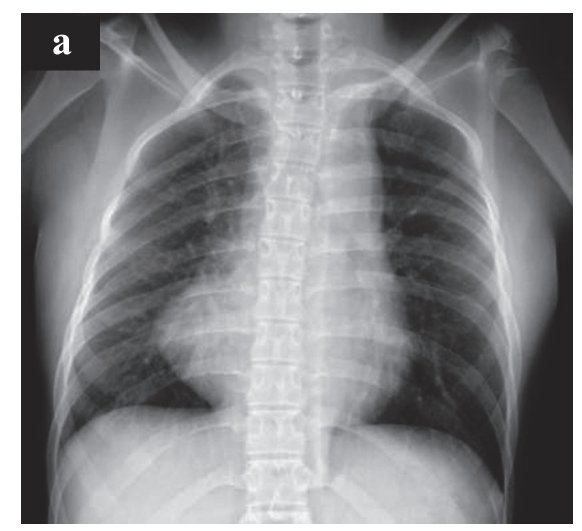

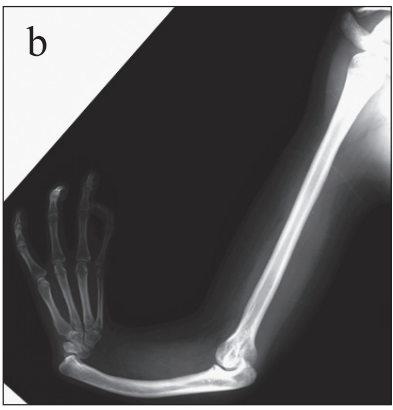

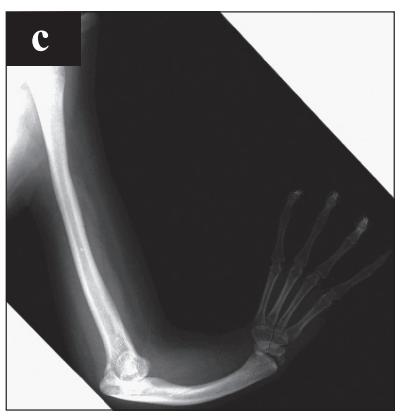

Fig. 4. Chest X-ray examination revealed dextrocardia (a), and an X-ray of her arms showed bilateral agenesis of the radial bone and first finger \{right arm (b),left arm (c)\}.

pancytopenia. Additional chemotherapy was not performed due to these severe adverse effects. Although her general condition had improved one month after the chemotherapy, her endocrine data did not show a significant improvement. She was discharged from our hospital and prescribed doxazosin $(6 \mathrm{mg} /$ day $)$ and carvedilol (2.5 mg/day). Her plasma norepinephrine level gradually became elevated to $60755 \mathrm{pg} / \mathrm{ml}$ over a period of one year after discharge. She was carefully followed up at the outpatient clinic and was prescribed an increased dose of doxazosin ( $7 \mathrm{mg} /$ day $)$, with the carvedilol ( $2.5 \mathrm{mg} /$ day $)$.

\section{Discussion}

Although the pathogenesis of pheochromocytoma remains unknown, recent studies have demonstrated its close relationship to mutations of the succinate dehydrogenase $(\mathrm{SDH})$ gene [10-12]. $\mathrm{SDH}$ is the major component of the mitochondrial complex II of the respiratory chain, and consists of four nuclear-encoded polypeptides: a flavoprotein (SDHA), iron sulfur protein (SDHB), and two integral membrane proteins (SDHC and SDHD) [13]. Of these components, it has been reported that the SDHB gene is more closely associated with malignant pheochromocytoma [14].
Holt-Oram syndrome is an inherited disorder that causes anomalies of the upper limbs and heart due to mutations in the TBX5 gene $[1-4,15] . T B X 5$ is a member of the evolutionarily conserved T-box family of transcription factor genes localized to chromosome 12q24.1. On the other hand, SALL gene mutations are reported to be the causes of Duane anomaly, anal stenosis, deafness and limb anomalies. Patients with Duane anormaly are often associated with radial sided hand malformations, atrial septal defects and other malformations. It is unclear at present whether these conditions are truly distinct or whether several overlap syndromes exist [15]. It has been reported that patients with typical radial ray malformations with Duane syndrome might carry a SALL4 mutation, region of chromosome 20 [16]. However, the clinical manifestations of Holt-Oram syndrome vary, and range from subclinical radiographic findings to overt, life-threatening disease. Cardiac abnormalities may include single or multiple atrial and ventricular septal defects, or they may be absent [5]. In our case, although a genetic analysis had not been performed, a diagnosis of Holt-Oram syndrome was made based upon the combination of clinical manifestations, including the complex congenital heart disease and bilateral agenesis of the radial bone and first finger. We should consider other disorders with limb and cardiac malformation caused by 
SALL4 mutation, since clinical features overlap with Holt Oram syndrome, thus genetic analysis is needed for further investigation.

To our knowledge, this is the first report of a case with the combination of malignant pheochromocytoma and Holt-Oram syndrome. Details of the mechanisms underlying these two rare disease states remain to be elucidated. The associations between TBX5, SALL4, and $S D H$ mutations have not been described. However, pheochromocytoma has been reported in patients with various other cyanotic heart diseases such as Fallot complex, single ventricle physiology, and tricuspid atresia $[17,18]$. Furthermore, a significant correlation between chronic hypoxia and peripheral neuroblastic tumors, including pheochromocytoma, has also been reported [19-22]. The hypoxic state stimulates catecholamine secretion from the adrenal medulla, and chronic endocrine hyperactivity may lead to hyperplasia and neoplasia [17]. Mutations of pheochromocytoma-related genes such as $V H L, S D H B$ and $S D H D$ have been demonstrated to be associated with increased hypoxic signals [23, 24]. Activation of the hypoxiainducible transcription factors HIF-1 and HIF-2 have been implicated in the pathogenesis of pheochromocytoma associated with $V H L, S D H B$ and $S D H D$ mutations [25]. HIF activation is said to be necessary and sufficient for many of the manifestations of $V H L$ loss of function. It has been suggested that mutation of the $\mathrm{SDH}$ gene results in tissue hypoxia, leading to angiogenesis and tumorigenesis [23]. Lee et al. suggested a pathway of genetic events leading to pheochromocytoma that germline $N F-1, c-R E T, S D H$ and $V H L$ mutation allow sympathetic neuronal progenitors to escape apoptosis and thereby neoplastic transformations occur [26] [27]. Taken together, these reports suggest that severe hypoxia could be the key mechanism for the combination of malignant pheochromocytoma and Holt-Oram syndrome in the present case. The genetic background of this phenomenon awaits further investigation.

Surgical treatment in this patient was not indicated because of her severe heart disease and the malignant nature of the pheochromocytoma. Without treatment, the 5-year survival is generally less than 50\% [15]. Alternatives to surgical resection include external beam radiation [28], cryoablation, radiofrequency ablation, transcatheter arterial embolization [29], and radiopharmaceutical therapy. All of these treatments were difficult for our patient. Chemotherapy with a combination of cyclophosphamide (Cytoxan), vincristine (Oncovin), and dacarbazine (DTIC-Dome) was performed. Since the patient experienced various and sustained adverse effects from the chemotherapy, she underwent the therapy only once. Her endocrine data did not show any improvement.

Considering the effects of pheochromocytoma on blood pressure, and the potentially cytotoxic effects of high circulating catecholamine levels on the myocardium [30,31], medical management of pheochromocytoma generally involves the use of an alpha-adrenergic receptor blockade. Beta-adrenergic receptor blockade is indicated after adequate alpha-adrenergic blockade in patients with tachycardia and catecholamineinduced arrhythmias [32]. In this case, the patient's blood pressure and heart rate were controlled at a normal level and her symptoms (sweating, headaches, palpitations, general fatigue, and vertigo) improved. She was treated with a combination of doxazosin at $6 \mathrm{mg} /$ day and carvedilol at $2.5 \mathrm{mg} /$ day and discharged from our hospital. Both hypertension and catecholaminedependent symptoms were well controlled for one year, although her plasma norepinephrine level gradually became elevated to $60755 \mathrm{pg} / \mathrm{ml}$.

In summary, we treated a 23 -year-old female with Holt-Oram syndrome diagnosed as malignant pheochromocytoma. This combination is rare, but the two diseases may be related through hypoxia. This instructive case reminds us to consider the possibility of pheochromocytoma with congenital heart disease when these types of unexpected or unusual symptoms are encountered.

\section{References}

1. Frota Filho JD, Pereira W, Leiria TL, Vallenas M, Leaes PE, Blacher C, Lucio E, Lucchese FA (1999) Holt-Oram syndrome revisited. Two patients in the same family. Arq Bras Cardiol 73: 429-434.
2. Brockhoff CJ, Kober H, Tsilimingas N, Dapper F, Munzel T, Meinertz T (1999) Holt-Oram syndrome. Circulation 99: 1395-1396.

3. Bohm M (1998) Holt-Oram syndrome. Circulation 98: 
2636-2637.

4. Shono S, Higa K, Kumano K, Dan K (1998) HoltOram syndrome. Br J Anaesth 80: 856-857.

5. Basson CT, Cowley GS, Solomon SD, Weissman B, Poznanski AK, Traill TA, Seidman JG, Seidman CE (1994) The clinical and genetic spectrum of the HoltOram syndrome (heart-hand syndrome). $N$ Engl $J$ Med 330: 885-891.

6. Averbuch SD, Steakley CS, Young RC, Gelmann EP, Goldstein DS, Stull R, Keiser HR (1988) Malignant pheochromocytoma: effective treatment with a combination of cyclophosphamide, vincristine, and dacarbazine. Ann Intern Med 109: 267-273.

7. Yurt A, Arda MN, Vardar E (2005) Metastatic pheochromocytoma of the thoracic spinal extradural space. Case report and review of the literature. Kobe $J$ Med Sci 51: 49-53.

8. Neumann HP, Pawlu C, Peczkowska M, Bausch B, McWhinney SR, Muresan M, Buchta M, Franke G, Klisch J, Bley TA, Hoegerle S, Boedeker CC, Opocher G, Schipper J, Januszewicz A, Eng C (2004) Distinct clinical features of paraganglioma syndromes associated with SDHB and SDHD gene mutations. Jama 292: 943-951.

9. Noshiro T, Honma H, Shimizu K, Kusakari T, Watanabe T, Akama H, Shibukawa S, Miura W, Abe K, Miura Y (1996) Two cases of malignant pheochromocytoma treated with cyclophosphamide, vincristine and dacarbazine in a combined chemotherapy. Endocr J 43: 279-284.

10. Astuti D, Latif F, Dallol A, Dahia PL, Douglas F, George E, Skoldberg F, Husebye ES, Eng C, Maher ER (2001) Gene mutations in the succinate dehydrogenase subunit SDHB cause susceptibility to familial pheochromocytoma and to familial paraganglioma. Am J Hum Genet 69: 49-54.

11. Niemann S, Muller U (2000) Mutations in SDHC cause autosomal dominant paraganglioma, type 3. Nat Genet 26: 268-270.

12. Amar L, Bertherat J, Baudin E, Ajzenberg C, Bressac-de Paillerets B, Chabre O, Chamontin B, Delemer B, Giraud S, Murat A, Niccoli-Sire P, Richard S, Rohmer V, Sadoul JL, Strompf L, Schlumberger M, Bertagna X, Plouin PF, Jeunemaitre X, Gimenez-Roqueplo AP (2005) Genetic testing in pheochromocytoma or functional paraganglioma. J Clin Oncol 23: 8812-8818.

13. Mannelli M, Simi L, Ercolino T, Gagliano MS, Becherini L, Vinci S, Sestini R, Gensini F, Pinzani P, Mascalchi M, Guerrini L, Pratesi C, Nesi G, Torti F, Cipollini F, Bernini GP, Genuardi M (2006) SDH mutations in patients affected by paraganglioma syndromes: a personal experience. Ann N Y Acad Sci 1073: 183-189.

14. Benn DE, Richardson AL, Marsh DJ, Robinson BG (2006) Genetic testing in pheochromocytoma- and paraganglioma-associated syndromes. Ann NY Acad Sci 1073: 104-111.

15. McDermott DA, Bressan MC, He J, Lee JS, Aftimos S, Brueckner M, Gilbert F, Graham GE, Hannibal MC, Innis JW, Pierpont ME, Raas-Rothschild A, Shanske AL, Smith WE, Spencer RH, St John-Sutton MG, van Maldergem L, Waggoner DJ, Weber M, Basson CT (2005) TBX5 genetic testing validates strict clinical criteria for Holt-Oram syndrome. Pediatr Res 58: 981986.

16. Kohlhase J, Schubert L, Liebers M, Rauch A, Becker K, Mohammed SN, Newbury-Ecob R, Reardon W (2003) Mutations at the SALL4 locus on chromosome 20 result in a range of clinically overlapping phenotypes, including Okihiro syndrome, Holt-Oram syndrome, acro-renal-ocular syndrome, and patients previously reported to represent thalidomide embryopathy. J Med Genet 40: 473-478.

17. Kita $\mathrm{T}$, Imamura $\mathrm{T}$, Date $\mathrm{H}$, Kitamura $\mathrm{K}$, Moriguchi $\mathrm{S}$, Sato Y, Asada Y, Eto T (2003) Two cases of pheochromocytoma associated with tetralogy of Fallot. Hypertens Res 26: 433-437.

18. Sparks JW, Seefelder C, Shamberger RC, McGowan FX (2005) The perioperative management of a patient with complex single ventricle physiology and pheochromocytoma. Anesth Analg 100: 972-975.

19. de la Monte SM, Hutchins GM, Moore GW (1985) Peripheral neuroblastic tumors and congenital heart disease. Possible role of hypoxic states in tumor induction. Am J Pediatr Hematol Oncol 7: 109-116.

20. Bockelman HW, Arya S, Gilbert EF (1982) Cyanotic congenital heart disease with malignant paraganglioma. Cancer 50: 2513-2517.

21. Stoll C, Alembik Y, Dott B (1995) Complex congenital heart disease, microcephaly, pheochromocytoma and neurofibromatosis type I in a girl born from consanguineous parents. Genet Couns 6: 217-220.

22. Tjeuw M, Fong J (1990) Anaesthetic management of a patient with a single ventricle and phaeochromocytoma. Anaesth Intensive Care 18: 567-569.

23. Dahia PL (2006) Transcription association of VHL and SDH mutations link hypoxia and oxidoreductase signals in pheochromocytomas. Ann N Y Acad Sci 1073: 208-220.

24. Dahia PL, Ross KN, Wright ME, Hayashida CY, Santagata S, Barontini M, Kung AL, Sanso G, Powers JF, Tischler AS, Hodin R, Heitritter S, Moore F, Dluhy R, Sosa JA, Ocal IT, Benn DE, Marsh DJ, Robinson BG, Schneider K, Garber J, Arum SM, Korbonits M, Grossman A, Pigny P, Toledo SP, Nose V, Li C, Stiles CD (2005) A HIF 1alpha regulatory loop links hypoxia and mitochondrial signals in pheochromocytomas. PLoS Genet 1: 72-80.

25. Pollard PJ, El-Bahrawy M, Poulsom R, Elia G, Killick P, Kelly G, Hunt T, Jeffery R, Seedhar P, Barwell J, 
Latif F, Gleeson MJ, Hodgson SV, Stamp GW, Tomlinson IP, Maher ER (2006) Expression of HIF1alpha, HIF-2alpha (EPAS1), and their target genes in paraganglioma and pheochromocytoma with VHL and SDH mutations. J Clin Endocrinol Metab 91: 45934598.

26. Lee S, Nakamura E, Yang H, Wei W, Linggi MS, Sajan MP, Farese RV, Freeman RS, Carter BD, Kaelin WG, Jr., Schlisio S (2005) Neuronal apoptosis linked to EgIN3 prolyl hydroxylase and familial pheochromocytoma genes: developmental culling and cancer. Cancer Cell 8: 155-167.

27. Maxwell PH (2005) A common pathway for genetic events leading to pheochromocytoma. Cancer Cell 8: 91-93.

28. Teno S, Tanabe A, Nomura K, Demura H (1996) Acutely exacerbated hypertension and increased inflammatory signs due to radiation treatment for metastatic pheochromocytoma. Endocr J 43: 511-516.

29. Watanabe D, Tanabe A, Naruse M, Tsuiki M, Torii N, Noshiro T, Takano K (2006) Transcatheter arterial embolization for the treatment of liver metastases in a patient with malignant pheochromocytoma. Endocr $J$ 53: 59-66.

30. Schiavi F, Boedeker CC, Bausch B, Peczkowska M, Gomez CF, Strassburg T, Pawlu C, Buchta M, Salzmann M, Hoffmann MM, Berlis A, Brink I, Cybulla M, Muresan M, Walter MA, Forrer F, Valimaki M, Kawecki A, Szutkowski Z, Schipper J, Walz MK, Pigny P, Bauters C, Willet-Brozick JE, Baysal BE, Januszewicz A, Eng C, Opocher G, Neumann HP (2005) Predictors and prevalence of paraganglioma syndrome associated with mutations of the SDHC gene. Jama 294: 2057-2063.

31. Mishra AK, Agarwal G, Kapoor A, Agarwal A, Bhatia E, Mishra SK (2000) Catecholamine cardiomyopathy in bilateral malignant pheochromocytoma: successful reversal after surgery. Int J Cardiol 76: 89-90.

32. Juan D (1982) Pharmacologic agents in the management of pheochromocytoma. South Med J 75: 211216. 